\title{
THE INSTITUTIONAL REPRESENTATION OF PARLIAMENT
}

\section{David Judge and Cristina Leston-Bandeira}

\begin{abstract}
Recent theoretical reconceptualisations of political representation and contemporary empirical analyses of parliamentary representation have largely neglected the representation of parliaments as institutions. As a consequence, relatively little attention has been focused upon what is being communicated to citizens about parliaments and upon the nature of the parliamentary institutions that citizens are expected to engage with. This is the neglected institutional dimension of parliamentary representation. Using interview data from 39 key actors in the Scottish, Westminster and European Parliaments, we analyse who act as 'claim-makers' on behalf of parliaments, the nature of these claims in different political contexts, and the 'symbolic intent' and claims associated with the architectural design of parliamentary buildings. We identify a basic paradox of institutional representation in that those who 'speak for' (most loudly and most persistently) and 'act for' parliaments as institutions are not primarily elected representatives but rather non-elected officials.
\end{abstract}

\section{Keywords}

Representation, Symbolic representation, Parliament, Representative claim-making

\section{Introduction}

Established democracies in recent decades have been confronted with manifest political disengagement, decreased levels of citizen trust in parliamentary representatives, and increased public dissatisfaction with the competence of parliaments (Dalton 2004; Norris 2011). In these circumstances, parliamentary institutions increasingly have had to 'become promoters of the values and operation of parliamentary democracy, bringing about a cultural and attitudinal shift within each institution' (Hansard Society 2010:68; IPU 2012:41). In analysing this shift the primary academic focus to-date has been upon democratic linkage of how parliaments engage with and inform citizens (see Kelso 2007; Clark and Wilford 2011; Walker 2012; Author 2012; 2014; 2016). This pre-occupation has reflected, in turn, a primary concern with what we identify in this article as the first dimension of parliamentary representation: of how the represented and representatives (as individuals and groups of individuals) interact. As a consequence, relatively little attention has been focused upon what is being communicated to citizens about parliaments and upon the nature of the parliamentary institutions that citizens are expected to engage with. This is the neglected institutional dimension of parliamentary representation: the representation of what parliaments 'are', what claims are made on their behalf and who are the makers of these claims. This second dimension is our focus in this article. In this dimension political representation is not confined to person-to-person or group-to-group interactions but encompasses a second systemic institutional dimension of political representation.

The institutions under examination in this article are parliaments, specifically those nested in the multi-layered representative systems of the United Kingdom. We argue that claim-based notions of representation and conceptions of symbolic representation, at the heart of recent re-conceptualisations of representation, provide valuable conceptual stepping-stones from the first person-to-person dimension to the second institutional dimension. In focusing upon this second dimension we seek to identify the differing contexts within which institutional representative claims are made for parliaments; who act as claim-makers on behalf of parliaments; the nature of the claims made; the symbolic prompts offered by parliamentary architecture; and the growing significance of institutional representation when basic assumptions about the legitimacy of parliamentary institutions come under sustained critical questioning.

The choice of the three legislatures in our sample enables an examination of the symbolic and institutional claims made by parliaments in distinctly different political, socio-cultural and 
constitutional contexts. The UK parliament is an historic institution embedded within an established demos defined by the boundaries of the UK state, yet confronted by claims of democratic deficiencies and assertions of pluri-national identities. The Scottish parliament is a relatively newly created institution at sub-state level reflecting a distinctive political national identity and afforded a blank slate in its approach to institutional structures and organisation. The European Parliament (EP) is an evolving, and expanding, purportedly sui generis, suprastate representative institution with multiple-demoi and no discernible coherent European political identity.

Our analysis is informed by qualitative data drawn from interviews with key parliamentary actors in each of the three parliaments. In total 39 interviews were conducted, as part of a broader project, with parliamentary officials and parliamentarians (12 from Holyrood, 16 from Westminster and 11 from the EP). All interviewees were selected through a purposive sample approach, according to the role they performed within the legislature in relation to institutional management and the delivery of public engagement services. The interviews were conducted, with a condition of anonymity, between November 2010 and January 2013. Other supporting data were derived from official parliamentary documents, parliamentary debates, and publically available documents relating to architectural design and public engagement strategies of each parliament.

\section{The 'representative turn', the 'constructivist turn' and the neglect of institutional representation}

A 'representative turn' has become increasingly noticeable in the study of democratic politics in recent years. Or, more particularly, analysts and theorists of democracy have attempted a re-conceptualisation and rethinking of political representation beyond a standard model of electoral representation (for overviews see Urbinati and Warren 2008; Näsström 2011). A standard model primarily 'reduces political representation to parliamentary representation' (Disch 2015:489). ${ }^{1}$ The representative turn, however, has recognised that, in the rapidly changing political environment of the $21^{\text {st }}$ century, 'the boundaries of [representative] democracy are seen as less distinct than before ... [and] it is no longer self-evident who speaks for whom, and by what authority' (Näsström 2011:501), and so has served to re-focus and re-orientate contemporary analysis of political representation. A central tenet of this rethinking has thus been a privileging of non-electoral, informal, self-authorised, and nonstatal variants of representation beyond the institutional configurations of elections and representative assemblies. In this re-conceptualisation, the macro-deliberative pre-eminence of state parliaments in the standard account has been questioned by broader and more radical notions of deliberation and democratic innovation in civil society (Smith 2009).

A 'constructivist turn' has also targeted the inadequacies of a standard model of political representation. A particularly prominent role in the recent re-conceptualisation of representation has been played by Michael Saward $(2006 ; 2010)$ in his articulation of the idea of 'the representative claim'. Indeed, Disch (2015:487) maintains that Saward's notion of representative claim provides the 'most influential statement of the constructivist position on political representation today'. ${ }^{2}$ In arguing that political representation is a process of claimmaking, Saward has sought to map out new theoretical territory and to blur the distinction between electoral and non-electoral representation. For the purposes of this article, however, Saward's conceptual map allows us to move beyond the terrain of non-electoral representation and to prospect the terrain of institutional representation.

Saward's ideas are of specific relevance for exploring the terrain of institutional representation in his formulation that a representative does not simply act for the represented but serves to construct the latter 'in the sense of portraying them or framing them in particular, contestable ways' (2010:47). We argue this is especially the case for the representation of political institutions. To make this case we need first to understand the concept of claim-making. Saward (2010:43) argues that claim-making consists of five interconnecting dimensions: maker, subject, object, referent, and audience; a maker, either as an individual or collective 
actor, constructs or makes claims; a subject is a signifier and stands for an object; a referent is the thing being represented; and an audience receives the claims made - and accepts, rejects or ignores them. Perhaps the simplest way to understand the concept of referent is as something that exists 'out there' it is 'a thing "as it is"' (Decreus 2013:37). When this 'thing' is represented, there is an act of interpretation or portrayal, which in itself is constitutive. In this manner, as Disch (2015:488-92) notes, the 'picturing', 'aesthetic', or 'performative' aspects of representation are central to constructivist theories. This invokes Pitkin's classic notion of representation as standing for, and draws our attention to her conception of symbolic representation, wherein '[s]ymbols ... represent their referent' (Pitkin 1967:94). Indeed, Pitkin was willing to acknowledge the capacity of inanimate objects and abstract ideas to serve as representative symbols: 'It is possible to speak of representing by inanimate objects' $(1967: 111)$ but this entails 'a special kind of activity ... the activity of making something represent' (1967:111). This special form of activity 'seems to rest entirely on people's belief or acceptance' (1967:110). This then raises the question of how these beliefs or acceptances are constructed. An answer has to be found beyond Pitkin's writings and in the activity of construction of meaning. In Mitchell's words (1962:123, quoted in Lombardo and Meier 2014:22): 'Symbolic objects derive their meaning from the actions and beliefs of persons, not from the objects themselves'. This statement, in turn, leads us back to Saward's (2010:36) claim that 'the thing represented is an idea of it, not the thing itself'. Indeed, Saward (2010:901) provides an insight into the significance of the 'symbolic architecture of our political system' in his acknowledgement that 'the encompassing domes of parliaments and legislatures' provide powerful symbols of the institutional configuration of representative democracy. Nonetheless, while symbolic representation is of importance for understanding the representation of parliaments as institutions; exactly how those symbolic cues are interpreted and received by audiences of citizens is dependent upon political context, culture and time. The importance of the constructivist turn, for our discussion, is in stressing that the cueing effect of symbols is not intrinsic but is interpreted.

Although constructivist ideas of claim-making and symbolic representation hold the potential to open up the analytical space of institutional representation, this dimension has been neglected in the recent representative turn, with little re-conceptualisation of what parliaments are and how they 're-present' themselves to the represented. In large part this is because parliaments have often been treated as 'ready-mades' and 'taken-for-granted' institutions of representation. They are, as Saward (2010:46) notes, ready-mades in that they are familiar institutions that tap into 'existing terms and understandings', they are readily identifiable, and they 'resonate' with citizens. They are taken-for-granted insofar as citizens may demonstrate limited knowledge of the specific activities and performance of parliaments, yet they have displayed, in Easton's terms, diffuse support for parliamentary institutions, despite declining levels of trust. Such support in liberal democracies is often tacit, even covert (Easton 1965:161), frequently unthinking, but, nonetheless, profound in the sense that it gives elected representative institutions 'a head start in terms of familiarity and perceived legitimacy' (Saward 2010:65). What also gives parliaments a head start is that, at 'a strongly abstract level', it is a state's legislature in liberal democracies that 'brings the nation together symbolically under one roof' (Saward 2010:90).

Yet, assumptions about the taken-for-granted and ready-made default status of elected representative institutions have come increasingly to be challenged by other non-electoral and non-traditional modes of representation. In response, established parliaments have been led towards more explicit constructions of institutional representational claims and greater promotion of the symbolic importance of parliamentary architecture and artefacts as representational forms of standing for the ideas of parliamentarism. ${ }^{3}$ Alternatively, newly established parliaments - with no, or few, historical residues of 'taken-for-grantedness' of their institutional legitimacy and status - have had to be proactive in generating their own institutional claims.

In reaching this point we have so far conjoined notions of symbolic representation and representative claim-making. For analytical purposes, however, these notions can be 
disaggregated by identifying two discrete, but often inter-linked, sets of claims associated with parliaments as institutions. One is concerned with 'symbolic intent' and the claims inhered within the architectural design of parliamentary buildings, and the invocation of the symbolism of those buildings in claims about their political significance (see Parkinson 2012:95-121). The other is concerned with the 'terms and understandings' of parliamentarism and the legitimation claims made on behalf of parliamentary institutions. At their starkest, these sets of claims reflect differing constructions of 'an institution'. For presentational purposes our discussion is structured around two, of many, approaches to answering the question 'what is an institution?'. First, an architectural/spatial approach, in which the physical form of a building signifies an institution's purpose. Second, an institutionalist conception of political institutions as 'rules of the game' (Rothstein 1996:145; Lowndes and Roberts 2013:46), where such institutions are identified as 'creat[ing] an interpretative order within which political order can be understood' (March and Olsen 1989:45).

This basic distinction is used to structure the following discussion, and to facilitate our examination of the nature of claim-making about parliament as an institution, and, more importantly, claim-making for the institution and on its behalf. This does not signify that these are the only sources of claim-making, as manifestly there are other significant 'makers' of claims about parliamentary institutions - often providing antithetical interpretations and constructions about the symbolic intent and legitimacy of these institutions. Our next step, therefore, is to examine the symbolic intent of parliamentary architecture in the UK, Scottish and European parliaments; before proceeding to an analysis of the utility of constructivist ideas in understanding the emerging practices of institutional representation.

\section{'Symbolic intent' and parliamentary architecture}

There is nothing new in noting that '[n]ational Parliamentary buildings are amongst the most prominent symbols of government in any polity' (Goodsell 1988:287; Rai 2010:285; Therborn 2014). But there is something relatively new in the 'spatial turn' taken by social scientists (see Parkinson 2012:6-8), which is of relevance to the representative turn taken by political theorists. The intersection of these 'turns' - in parliamentary architecture - is our main concern here. In essence the symbolism of parliamentary architecture provides cues to audiences constituted of state citizens. In this sense, parliamentary architectures serve as powerful symbols as to what parliaments are and what their occupants claim to do in relation to citizens and state. Indeed, the design of parliamentary buildings provides architectural cues as to their political importance. Typically, parliaments are designed with what Parkinson (2012:95) calls 'symbolic intent'. Significantly this symbolic intent varies across time, space and cultures.

The UK parliament traces its architectural heritage back to the $11^{\text {th }}$ century, with Westminster Hall - built under William II and conceived as 'a project to impress his new subjects with his power and the majesty of his authority' (UK Parliament 2015a) - still standing today. Westminster Hall was initially part of the King's palace and the UK parliamentary buildings are still known as Westminster Palace. Ultimately, these buildings came to serve as symbolic representations of the constitutional distinction between Lords and Commons in physically separate, but proximate, chambers unified under the architectural canopy of a royal palace. The symbolism of parliament's medieval architectural origins withstood later remodelling of the Palace of Westminster until the destruction of both chambers and other parliamentary buildings in the fire of 1834 .

The rebuilt palace integrated the surviving medieval buildings into the new design. The choice of the Gothic style - prescribed by a Royal Commission and realised by Barry and Pugin was, at one level, a practical design solution as it allowed for the incorporation of surviving medieval structures. At another level however, perpendicular gothic 'was viewed by the midnineteenth-century Englishman as inherently ... English ... and because of the long association of Parliament with the medieval palace of Westminster the Gothic style was viewed as being connected with the parliamentary form of government' (Roth and Roth Clark 2014:510). When completed and 'towering over the modest brick-built Georgian terraces of 
Westminster, the new Palace had an enormous effect on the imagination of the Victorian public' (UK Parliament 2015b). But exactly what effect was intended is open to dispute (see Rorabaugh 1973 and below).

The later decision to maintain the basic shape, dimensions and Gothic form of the Commons chamber when it was rebuilt, after its destruction by bombing in 1941, was famously supported by Churchill in the Commons in his oft-quoted statement that: 'we shape our buildings and afterwards our buildings shape us' (HC Debates, 28 October 1943:col.403; see also Nicholson, HC Debates, 28 October 1943:col.437).

The Scottish Parliament, built at the turn of the $21^{\text {st }}$ century at Holyrood in Edinburgh, was designed with clear symbolic intent. The architects, led by Miralles, made clear in their design portfolio the political implications inherent within their design: 'The crucial idea that sustains it is that: the Parliament is the land because it belongs to the Scottish land. This is our goal ... we don't want to forget that the Scottish Parliament will be in Edinburgh, but will belong to Scotland, to the Scottish land' (EMBT 1998). Indeed, Scottish sociologist David McCrone captured the symbolic power of the new parliamentary building in his statement:

[b]uildings are not inert, not simply the outcomes of decisions; they have the power to signify and move to political action. ... Miralles used his [design] motif in a highly symbolic way, to evoke fluidity and movement, of parliament running into the land, into Scot-Land. ... This is not an administrative office block, but the democratic crucible in which Scotland's future will ultimately be decided, and on a map as yet unwritten. (McCrone 2005:24-5)

But without prior knowledge of Miralles' design concept - applicable to the bulk of the Scottish populace - the symbolism of the Holyrood parliament prompted divergent and often counterintuitive interpretation (see below).

The European parliament with its modernist buildings in two cities, Brussels and Strasbourg, and its historical roots and administrative residues in a third city, Luxembourg, provides no exception to the use of architecture for symbolic purposes. In contradistinction to the other two parliaments, however, the EP does not represent the unifying core of a state, nation or nationstate. Instead, the geographical dispersion of parliamentary buildings is portrayed as a representation of EU governance itself. In McNamara's (2015a:105) words: 'The buildings, the siting of those buildings and the process of locating the physical governance of the EU all work symbolically'. Thus, the notion of a dual-seat parliament in Brussels and Strasbourg could be interpreted as 'a striking example of "localizing" the EU in national settings, moving outside the Brussels bubble and physically into member states' (McNamara 2015b:76). Yet, equally the dual-seat symbolism was open to more sceptical interpretation by the parliamentary occupants of the buildings and external critics alike (see below).

Moreover, the symbolism of the EU's institutions, captured in their spatial dispersion and architectural design, has evolved and mutated overtime: from an initial stealth design to minimise the appearance of concentration of power (McNamara 2015a:106) whereby Brussels became the informal EU capital; through to more ambitious design strategies from the late1980s onwards and the emergence of a new EU institutional complex in Brussels, which symbolised the integrationist intent and upward power-flows codified in a succession of EU treaties. In tandem, the Weiss hemicycle, built in Strasbourg in the late-1990s, was envisaged by its architects as an expression of the culture of Europe and its history: 'The architecture of the European Parliament ... is also representative of ... the democratic institution behind the building: ... It is a contextual building in the broad sense of the word. It embodies the strength of unity and the openness of democracy' (Architecture Studio 2015).

\section{Interpreting architectural symbols}

Symbolic representation, as noted above, is not merely the preserve of the referent and the making of symbols, it is equally concerned with the interpretation of symbols by makers and 
by audiences. Parkinson (2012:97) notes for example that 'the fact that a building was constructed for a given symbolic purpose, tells us relatively little about how it is actually seen and used ... [c]ontext is what determines how a symbol is received'.

Indeed, the rebuilding of the Westminster parliament after 1834 illustrates this point vividly for, as Cannadine (2000:19) argues, Barry and Pugin's intentions, in tracing the medieval associations of the British representative institution, may have been 'profoundly conservative, hierarchical and anti-democratic'. Certainly, their design consciously provided an architectural counterpoint to that of revolutionary France. Yet it should also be remembered that: 'Any cueing effects of the new Houses of Parliament were weak at best [and] the buildings took on more democratic overtones as more democracy was enacted within them' (Parkinson 2012:98). In this regard interpretation of the Westminster Palace's symbolism changed rapidly in the $19^{\text {th }}$ century and came to signify something quite different to the original intent of its designers (Cannadine 2004:13). This was the symbolic intent invoked by Churchill in the 1943 debate noted above. At the time, there was, as Shenton observes (2016:4 emphasis in original), a strong conviction among MPs that 'the nineteenth-century House of Parliament was the ultimate architectural manifestation of representative democracy'. The representational cues - offered by the Gothic architectural embodiment of what Churchill described as the 'most powerful assembly in the whole world' (HC Debates 28 October 1943: col.408) - were profoundly positive.

Some 70 years later, however, the crumbling edifice and outmoded interior of Westminster, and a potential refurbishment fee of some $£ 5.7 \mathrm{bn}$ (Deloitte 2014), provided profoundly negative cues to MPs and a less deferential and more cynical public audience. In this context, calls for a new $21^{\text {st }}$ century parliament building designed to symbolise new ways of doing politics became ever more strident and persistent. Many MPs were quick to point out how the initial symbolic intent of the Barry/Pugin design had transmogrified to the extent that the Palace of Westminster now reflected 'in many ways a by-gone era and require[s] fundamental change to properly serve a modern democracy' (Roger Mullin MP 2016). Labour MP Chuka Umunna (2016) was convinced that: 'We cannot continue this way of doing politics in a $21^{\text {st }}$ century world .... Let us get out of the Palace of Westminster, which ... should be changed into a museum, and let Parliament function in a modern building, in a modern way'. Indeed, the degree of conceptual travel from the original mid $-19^{\text {th }}$ century symbolic intent of Westminster to the interpretation of that intent two centuries later bears testament to Therborn's (2014:335) observation that there are multiple ways of seeing and reading any given symbol.

Similarly, the symbolic intent of the Scottish parliament's design has been open to contrasting interpretations in its relatively short life. On the positive side, the chamber and public spaces of Miralles' interior design have impressed, even if many visitors remain unsure about his vision. The symbolism of the building has been interpreted officially by parliamentary tour guides, and in 22 webpages of the parliamentary website explaining the meaning of Holyrood's architecture and detailing the project history of the building. On the negative side, the symbolic intent of the Scottish parliament has remained ambiguous. Despite the building winning numerous architectural awards, its political signposts have been interpreted negatively by sections of expert and lay publics alike. Thus, for example, Spring noted (2010): 'If any building really does need to have an iconic form, it is a national legislature. ... this just doesn't exist [at Holyrood]'. He went on to quote one MSP's belief that, 'You don't walk past this building saying, "That's a big impressive building, that's a parliament." You walk past saying, "Why?"'. Indeed, the public remained largely clueless (and often antipathetic) as to the building's symbolic prompts, with a survey in 2005 recording that the Scottish parliament headed the list of Britain's 'most vile buildings' (The Observer, 7 August 2005). Moreover, for significant sections of the Scottish media, and for devolution sceptics, the intricacies of the architectural design, subsequent problems with construction and cost-overrun, simply served as a metaphor for the inherent deficiencies of the institutional design of devolution (Mitchell 2004:35; Author 2005:183). 
In the case of the EP, whereas the architects sought to symbolise the transition of centralised state power to the openness of European democracy, their work has been interpreted differently when refracted through eurosceptic ideational lenses. This interpretation is vividly reflected in Daniel Hannan's (Conservative MEP) statement:

The European Parliament's gargantuan edifices are the perfect symbols of the larger [EU] ...The European Parliament, in short, is the European Union's objective correlative: the thing that expresses, in physical form, the project's abstract flaws. Prodigal, labyrinthine, constantly expanding, and wanting any sense of proportion, it is the perfect symbol of the whole Euro-racket. (Hannan 2015)

Less sceptical MEPs, for example members of the cross-party and pro-European Single Seat campaign group, were equally aware of the negative symbolism - invoked by the financial, environmental and political costs - associated with a dual-seat parliament.

\begin{abstract}
'Terms and Understandings': Institutional Representative Claims and Claim-Makers While symbolic representation is of importance for the representation of parliaments as institutions, the preceding discussion has highlighted how the cueing effect of architectural symbols is not intrinsic but is interpreted. In this specific process of interpretation, and in processes of institutional representation more generally, the making of claims - of providing institutional meaning - are of vital significance. We now turn attention, therefore, to who act as institutional claim-makers, the nature of the claims made, the intended audiences to which claims are addressed, and how institutional representation varies in our three case studies according to their respective contexts.
\end{abstract}

\title{
Who makes institutional claims?
}

\section{i) Elected Representatives: Crosscutting representative claims}

It is relatively easy to identify who are not the primary actors in making institutional claims. Paradoxically, elected representatives, who are the prime makers of electoral representative claims, are at best tangential makers of institutional representative claims. Whereas elected representatives can legitimately claim to act for, speak for, or stand for, their construction of their constituencies within the frame of electoral politics, this is a first-dimensional set of claims. The representative, whether as an individual or part of a collectivity of individuals (most notably party, government, or parliamentarians), makes a claim to represent the represented, whether as individuals or collectivities of individuals (most notably as members of geographical constituencies, political parties, or nations and/or states). This is a two-way process as representatives may also serve to represent the constructed claims of the collectivities (especially of party, government or state) back to the represented (see Mair 2009:6). In this process elected representatives may be identified as the makers of claims about their parties or about governments (supportive or otherwise) or about the nation and/or state, but only tangentially about parliament as an institution. Whereas the other collective forms have some existence beyond parliament; parliament itself, as a collectivity, does not have an institutional representational existence other than as the sum of disparate other 'firstdimension' forms of representation.

In the case of the UK parliament, Kelso (2007:371-2) pointed to this phenomenon in her observation that: 'The public regularly view politicians as party members, as government members and as constituency MPs, but rarely as parliamentarians ... Parliament struggles with its identity as a holistic institution' (see also Author 2014:422). Likewise, MPs construct different representations of themselves in relation to different audiences, whether these be in relation to geographical constituencies, political parties, government (support for or critic of), nation or state. These constructions are normally portrayed as 'roles', as patterns of understanding and behaviour held by MPs, and cursory examination of UK MPs' websites confirms that these roles do not privilege the institutional role of parliamentarian. Individually, elected representatives rarely act as claim-makers on behalf of the institutional collectivity of the Westminster parliament. Indeed, MPs often gain political advantage by making anti- 
institutional claims; either as members of new type or protest parties, as party mavericks or as part of their electoral strategy. Thus, for example, as an anti-UK-system party, the Scottish National Party (SNP), secures political advantage in the UK Parliament from claiming that Westminster is a 'totally defunct institution' (Mhari Black, SNP MP, The Guardian, 17 March 2016). Party mavericks, such as former Conservative Zac Goldsmith, seek to enhance their populist credibility through interpreting Westminster as an institution insulated from the electorate (HC Debates 21 October 2014 vol. 586:col.791). Even Nick Clegg (2013), as Deputy Prime Minister, saw electoral advantage in criticising the 'Westminster bubble'. Similarly, Andy Burnham during his campaign to become Leader of the Labour party in 2015 saw partisan advantage in repeatedly decrying the Westminster bubble (Cowley 2015).

In this sense the Westminster parliament takes on a 'hollowed-out' representative institutional form: it is populated by active person-to-person claim-makers but those same claim-makers do not primarily stand for, or make positive claims on behalf of, the institution itself. Institutional claim-making has become largely the preserve of those insulated from the demands of person-to-person representation - either through the adoption by elected representatives of designated collective institutional roles (such as the Speaker of the House of Commons in Westminster, the Presiding Officer of the Scottish Parliament or the President of the European Parliament) or by non-elected parliamentary officials.

In Scotland, while the aspirations of the Scottish parliament's political designers matched those of its architectural designers - for a more transparent, participatory, inclusive and easily accessible institution that brought together the Scottish nation under one roof, rooted in a new and consensual politics - these ambitions were, in Mitchell's words (2010:107), 'given little or no substantive institutional form'. Such a basic consensus of what the parliament was (representation as standing for) and what it was intended to do (representation as activity) was largely illusory. On both counts its own members found it difficult to construct consensual claims on its behalf. There was a fundamental partisan divide about how the Scottish parliament should be conceived (Mitchell 2014:156-86; Johns and Mitchell 2016:158-80). The significance of this partisan divide, which reflected a more deep-seated neo-unionist/neonationalist divide (Keating 2009:130), was that it made it difficult for MSPs to make claims for the Scottish parliament in its own right rather than as a proxy for a different institutional order - of, respectively, a union UK state or an independent Scottish state. These difficulties were compounded by the fact that the consensual aspirations of new politics were rapidly reconfigured into adversarial political realities, and bifurcation associated with executive dominance (Cairney 2015:219-20). Thus, the very characteristics that constrained the capacity of MPs in Westminster to act as claim-makers for the institution of parliament, qua parliament, were replicated in Holyrood. This point was acknowledged by one Holyrood official who noted in interview, 'when you're working in an organisation, ... usually organisations do speak with one voice largely. When you work in a Parliament you don't speak with one voice. We've got 129 [elected] Members, but they're very capable of having opposing and critical views of what the institution does' (Interview 26).

Whereas the case can be made that, paradoxically, elected representatives in the UK and Scottish parliaments - the prime makers of electoral representative claims - are at best makers of tangential institutional representative claims, a stark qualification to any general observations to be derived from these cases is provided by the EP. The EP is often treated as a sui generis institution operating in a broader sui generis EU institutional matrix. The exact nature of this matrix is not the prime concern here. What is of interest here, however, is how the EP became a parliament, how the representation of that institution developed over time and who acted as the prime institutional claim-makers. In the first instance, the EP was not established as a parliament in the received sense of the term. It was conceived, by Monnet, as a 'rudimentary assembly' or at best a 'parliamentary control organ' (Monnet in Rittberger 2005:28). Democratic participation through an elected representative institution was, therefore, something for the future. 
The promotion of that parliamentary future was inextricably associated with institutional claimmakers who created an image, a representation, of what the EP was and where it should be situated in relation to other institutions. Members of the Assembly effectively identified themselves as part of a collective institution defined in terms of its distinctiveness from other EU institutions and national representative institutions. That distinctiveness, often portrayed as an embattled institutional status, was an essential feature of the representational claims made on behalf of the Common Assembly and of its institutional successors (Corbett 1998; Priestley 2008:ix-xxii; Corbett et al. 2011:382-97).

In other words, the EP's organisational form and structural location mitigated the cross-cutting segmentation of institutional claims apparent in other parliaments. First, in the absence of overlapping legislative and executive leadership positions in the EP. Second, in the majority voting requirements and the nature of coalition formation amongst political groups in the EP, which serve to signal ideological competition while still presenting a united institutional front in the EP's interactions with other institutions. Third, in institutional organisational structures, reflected in the composition and role of the Bureau with its responsibility for administrative and managerial matters in the EP. Whereas the House of Commons' Commission and the Scottish Parliament's Corporate Body act essentially in a rubber-stamp capacity, with MPs by-andlarge deferring to the decisions made by parliamentary management services, MEPs in the EP's Bureau take an active role in developing their vision for the institution as part of their policy portfolios (Interview 6; Interview 7; Interview 16; Interview 21; Interview 27; Interview 29). One interviewee made this clear by identifying the importance of Bureau members, and MEPs more generally, in representing the institution of Parliament per se (Interview 6). This amplifies the broader point that MEPs have historically acted as institutional claim-makers, representing the EP as both vision and embodiment of a democratic Europe (European Parliament 2009; Priestley 2008:23-44). Admittedly, the more ideologically polarised and fragmented composition of the EP, particularly since 2014, with increased representation of Eurosceptic and nationalist parties, found reflection in increased anti-institutional, antiintegrationist and anti-parliamentary claims made internally with the EP.

\section{ii) Parliamentary Officials: proactive institutional claim-makers}

In recent times of systemic dislocation, when the 'taken-for-grantedness' of established parliamentary institutions has become subject to reappraisal and hence to contestation - in the form of non-traditional, non-electoral representational practices, and in conceptual rethinking of representation - then the requirement for institutional representation, for claims to be made about and on behalf of parliaments themselves, has been thrown into stark relief. In these circumstances, or where newly created parliaments seek to assert their democratic credentials, public engagement strategies have come to be elevated in the corporate priorities of many parliaments. These are not simply educational or informational strategies. They are, more significantly, representational strategies. As Author (2016:13) notes: 'behind the planning of public engagement, there is an explicit effort therefore in developing amongst the public an appreciation of the institution as part of the fabric of their lives'. This task of appreciation building, as noted above, has largely accrued to non-partisan institutional claimmakers (such as the Speaker of the House of Commons) or by parliamentary officials and services.

The narrative of such claim-makers is consciously institutional. In the words of one UK parliamentary official: 'It's not our job to disseminate the work of Members, ... it would be inappropriate for us to do so. We're here to promote awareness of the institution and the processes of the institution' (Interview 13). This view was reiterated by several other interviewees: 'Parliaments in my view are not the property of parliamentarians, they are not the preserve of politicians, they belong to the people out there and we must never forget that in what we do in terms of our outreach and the way we make information available' (Interview 56) and 'we don't take the place of that relationship that Members have with their constituents, but we rather work in a different space' (Interview 11). 
In Westminster, indeed, the defence of the institution seems primarily to reside in the hands of officials, particularly since the 2009 MPs expenses crisis. Post-2009, MPs retreated even further from their already minimalist levels of claim-making on behalf of the institution of parliament. This institutional representative void contributed to the systematic expansion of the UK's Parliament's outreach and educational services (Author 2016), with the explicit objective of spreading 'awareness of the work, processes and relevance of the institution of parliament' (HC 697 2012: Ev w62). As one of our interviewees confirmed: 'the expenses issue highlighted the fact that Parliament needed to engage much more with the public and explain itself much more to the public' (Interview 43). Indeed, the Hansard Society recognised that such outreach work added 'an extra dimension to [the] strategy of promoting Parliament as a unified institution' (Hansard Society 2006:5).

Similarly, in the Scottish parliament, officials readily make claims on behalf of the institution. In interview officials clearly saw themselves as the defenders of the institutional image of an open, consensual and transparent institution, and one that serves as the symbolic representation of the nation of Scotland. Officials were very conscious of being the key ambassadors of the institution: 'the engagement work that we do ... is about trying to create a positive image for the parliament and to position it in Scottish people's minds as an institution that is actually here and it's working for you and all the rest of it. We're very conscious that we are ambassadors for the parliament in that respect' (Interview 33).

MEPs, as noted above, historically have been more active institutional claim-makers than Westminster MPs or MSPs. In this task they were aided 'by a generation of officials who dedicated their professional lives to assisting MEPs to reinforce the institution's role' and who undoubtedly assisted 'in the remarkable rise in influence of the parliament' (Corbett et al. 2011:230; see also Author 2008:166). These activist officials were to be found pre-eminently in the EP's legal services and the most prestigious committees, but institutional reinforcement was also provided by what is now the Directorate-General for Communication. As Laursen and Valenti observe, the EP's press officers 'see themselves as the EP's institutional voice' and are 'very aware that they are in the business of strategic communication, and that their objectives include increasing the EP's visibility in the media and shaping the EP's image' (2014:34-35, emphasis added), a view confirmed by several of our interviewees (Interview 9; Interview 2; Interview 5). One of Laursen and Valenti's interviewees went so far as to acknowledge that their aim was 'to sell' the institution. Likewise, one of our interviewees spoke specifically about 'selling' the EP as an institution (Interview 1). Another of our interviewees noted the distinction between the 'institutional representative' claims made by officials and the 'electoral representative' claims made by MEPs and EP party groups:

one of our roles must be taking care of the European Parliament's reputation and this is something which cannot be done, which shouldn't be done by the political actors, by the political groups, by the Members themselves. They have their own agendas, they have their own purposes and their own strategies, they are not there for protecting the European Parliament or for projecting the European Parliament, but their political opinions and their political work. This is not an institution which has two or three hundred years of history so it means that it is not always well known and it is not always well understood. And this is probably one of the important roles of an institutional press service and an institutional communications service. (Interview 7)

In this shaping and selling of the EP, officials are engaged in claim-making - in providing institutional meaning.

\section{Nature of institutional claims}

We now turn to what constitute institutional claims. In essence the institutional claims made about parliaments are first-order legitimation claims. In an era when the electoral claims of parliamentary representatives are counterposed by non-electoral representative claims and undermined by citizens' distrust, the legitimacy of electoral processes and institutions - and 
the wider democratic systems within which they are nested - come under sustained challenge (Dalton 2004; Norris 2011). In these circumstances the default recourse, to claims of diffuse support and of the virtues of 'taken-for-grantedness' of parliamentary institutions, become less convincing and defending the virtues of electoral representative institutions becomes particularly pressing for institutional claim-makers.

This was clearly articulated by several interviewees at Westminster: '[our aim is to show that] Parliament is a worthwhile institution, it's something that should be valued and is relevant to people's lives ... we want people to realise that Parliament is the heart of our democracy' (Interview 11); and 'the whole goal ... is to present the House of Commons as the central institution in our democracy' (Interview 18). This latter senior official went on to observe that:

unless someone stood up for Parliament as an entity we might lose it. It wouldn't be seen as precious. ... now we have quite a clear appreciation that the image of Parliament is very important. [And] implicit in that is an acceptance that the House has a personality, the House has a reputation that needs to be protected and built up. So looking at how well respected the institution is, is now the number one thing on the list of what we are seeking to do. (Interview 18)

In Scotland, parliamentary officials identified their key tasks to include not only the promotion of the Scottish Parliament as an institution, but also a broader role in promoting its links with civil society and its integration into the fabric of Scottish society and politics. In the first instance they emphasised the representation of the collective institution above the segmented organisational interests of its constituent elements. Thus one official noted: 'You can't consider an individual committee above the parliament's image or an individual convenor above the parliament's image. It's always got to be about the parliament ... We've got to put parliament first and not the convenors or individual members unless it's the Presiding Officer who is obviously part of parliament's overall image' (Interview 32). In the second instance, as one senior official observed, a broader representative claim is rooted in the fact that the Scottish parliament 'very much sees itself as playing a role in the cultural life of the country. So we like to promote Scotland and promote the best of Scotland in terms of what we do in the Scottish parliament' (Interview 26).

The representational move identified by Scottish parliamentary officials, of locating the institution of parliament within a broader conception of a civic-nationalist democratic frame, was echoed and amplified by EP officials who identified their task not simply as articulating the democratic credentials and the electoral legitimacy of the EP, but also rooting the EP within the integrationist EU project of an ever closer union. Indeed, the interviewed EP officials identified themselves not simply as institutional claim-makers for the EP, but also as claimmakers for the EU. The representation of the EP as an institution was inextricably linked to the representation of a legitimate European polity. As one official stated, the image of the EP should be encapsulated in the word 'democracy': 'For me it should be a democracy in Europe. ... Europe is the project you can offer your kids and it's even more than this, that's the only project you can offer your kids ... Europe is great. I mean Europe gives you the possibility to travel, to settle. ... And yes, the European Parliament is a parliament and it's a democracy in Europe' (Interview 1). Indeed, another senior official stressed the inextricable linkage of the institutional standing of the EP, and its legitimation claims, to the broader EU integrationist project:

At the European level this is much more difficult than at the national one, because at the national one probably people do not ask themselves about the sense of an institution or the necessity of having this institution. This is something which is there, so no questions about it. In our case we belong to something which is always discussed which is the European Union and which is what we call the European construction, so it means that we are weaker from this point of view and that we should also be more active than other institutions in explaining our work. So of course the Parliament has the full legitimacy 
which comes from the fact that the Members are elected in general, open elections, but in some way and at the same time we have to look for this legitimacy. (Interview 7)

\section{Audience(s) for institutional claims}

Our focus so far has been upon institutional representation, conceived in terms of symbolic representation and claim-making processes. Yet, it should be noted that Saward's notion of the representative claim incorporates audiences as an essential part of his analysis. As he states: 'representative claims can only work, or even exist, if audiences acknowledge them in some way, and are able to absorb, reject, or accept them, or otherwise engage with them' (Saward 2010:48). Saward's articulation of the types of audiences and their connections to types of constituencies is complex and beyond the immediate scope of our discussion. Nonetheless, his distinction between intended audiences and actual audiences enables us to foreground our discussion upon the former rather than the latter. An intended audience, for Saward (2010:50) is 'the group to which a claim is addressed' and is 'maker-driven'; an actual audience is 'the group whose members are conscious of receiving ... the claim' and is 'recipient-driven'. At this stage in our research, data on the reception of institutional claims is unavailable. Our interviews did provide, however, some indication of how institutional claimmakers conceived of their intended audiences and how they sought to identify variegated audiences.

Manifestly 'the general public' is the key audience for the institutional claim-makers in our sample, with all of our interviewees referring in general terms to 'the people' or 'the public'. In each parliament, however, officials recognised more specific target audiences: primarily young people and the disengaged. Thus, one official from the Scottish Parliament, in explaining the importance of the parliament's educational programmes, observed 'our key priorities are really getting [at] mainly young people and some adults, [to] let them learn about the Scottish Parliament' (Interview 33). Similarly, an official in Westminster - in explaining the main aim of the new engagement services - acknowledged that it was primarily a response to 'realising that there was a public that was not getting engaged simply by what individual representatives were doing' (Interview 18). This aim is explicitly articulated in the official description of the responsibilities of the Commons' Outreach and Engagement Group: '[to] engag[e] with people who Parliament has not yet reached and adding value to the business of Parliament by diversifying the range of people who engage and participate' (UK Parliament 2016). For our interviewees in the EP, the non-voting public constituted a particularly important audience. All EP interviewees justified their engagement activity as ultimately aimed at raising turnout. As one engagement official observed: 'Of course I'm not the one campaigning. But whatever we can do to show what the Parliament's doing ... I hope will at the end have an impact on the turnout. ... at the back of my mind that's what we should all keep in mind. Get a big turnout' (Interview 1).

Another intended audience is the media, with the development of press offices and media relations units in all three parliaments acknowledging the importance of these audiences, which can help both to disseminate and appraise - not necessarily favourably - institutional claims. The significance of these media audiences was recognised in turn by our interviewees (Interview 9; Interview 33; Interview 43). Increasingly, civic society and advocacy groups which Saward (2010:186) identifies as 'effective audiences' with the resources and social capital to act as opinion-shapers with respect to claims - have also been targeted by institutional claim-makers. The identification of community groups as specific audiences is particularly clear in programmes developed by the Scottish and the UK Parliaments. Thus one Scottish parliament official drew attention to 'our community partnerships project and that's really about working with groups over a 12-month period' (Interview 33), while a Westminster official noted a strategy of 'work[ing] with organisations who want to campaign' (Interview 13).

\section{Conclusion}


Institutional representation has been a neglected dimension of both recent reconceptualisations of representation and of empirical studies of parliamentary representation. As a first step in remedying this neglect, we have argued that key notions in the reconceptualisation of political representation - symbolic representation and representation as claim-making - provide clues as to how parliaments, as institutions, are portrayed or interpreted. As a second step, we examined the practice of institutional representation in relation to the Scottish, UK and European parliaments. This practice varies in accordance with the extent to which the status of parliaments in our sample, as 'ready-made' or 'taken-forgranted' institutions, is either under construction or under challenge. Institutional representation and institutional claim-making is of significance when assumptions about the institutional legitimacy of established parliaments are challenged (as in the case of the UK parliament), or are in the process of being made (as in the case of the Scottish parliament) or exist in putative form in a perceived sui generis system (as in the case of the EP). In these circumstances the institutional claims made about, and on behalf of, parliaments are first-order legitimation claims.

If, as we argue, institutional representation has assumed greater importance - as citizens' distrust and disengagement from parliaments appear to have increased - then it is necessary to understand who makes representative claims on behalf of parliamentary institutions. Paradoxically, elected representatives, who are the prime makers of electoral representative claims, are at best tangential makers of institutional representative claims in two of our sample parliaments - the Scottish and UK parliaments. In the case of the EP, however, its organisational form and structural location in the EU's polity has served to mitigate the crosscutting segmentation of institutional claims associated with partisan and executive hierarchies in the other parliaments.

In all three parliaments public engagement strategies are an integral part of their corporate priorities. Yet, these are not simply educational or informational strategies; they are, more significantly, representational strategies. These strategies have largely depended for their implementation upon non-partisan institutional claim-makers or parliamentary officials. The ultimate paradox of 'institutional representation', therefore, is that the people who 'speak for' (most loudly and most persistently) and 'act for' parliaments as institutions are not primarily elected representatives but rather non-elected officials. In an epoch when elected representatives are cowed by populist claim-makers - demagogues, challenger parties and protest social movements - and confronted routinely by claims that are intrinsically antiparliamentary and anti-elitist (in a specific sense of the questioning of elected representatives and political establishments), this paradox of the institutional representation of parliaments raises questions that should not only be of concern for representative theory but, more fundamentally, should also be of concern for representative democracy itself. 


\section{References}

Alonso, S., Keane, J. and Merkel, W. (2011) 'Rethinking the Future of Representative Democracy', in S. Alonso, J. Keane, and W. Merkel (eds.), The Future of Representative Democracy. Cambridge: Cambridge University Press.

Architecture Studio (2015) European Parliament, available at: http://www.architecturestudio.fr/en/projects/str2/european_parliament.html.

Cairney, P. (2015) 'Scotland's Future Political System', Political Quarterly, 86(2), 217-25.

Cannadine, D. (2000) 'The Palace of Westminster as Palace of Varieties', in C. Riding and J. Riding (eds.), The Houses of Parliament: History, Art, Architecture. London: Merrell, pp.1129.

Cannadine, D. (2004) In Churchill's Shadow: Confronting the Past in Modern Britain. Oxford: Oxford University Press.

Childs, S. and Lovenduski, J. (2013) 'Political Representation', in G. Waylen, K. Celis, J. Kantola, and L. Weldon, (eds.), The Oxford Handbook of Gender and Politics. Oxford: Oxford University Press.

Clark, A. and Wilford, R. (2012) 'Political Institutions, Engagement and Outreach: The Case of the Northern Ireland Assembly', Parliamentary Affairs, 65(2), 380-403.

Clegg, N. (2013) 'Speech to the Liberal Democrat Autumn Conference', available at: http://www.libdems.org.uk/nick_clegg_speech_to_the_liberal_democrat_autumn_confere nce.

Cowley, J. (2015) 'Andy Burnham Thinks He is an Outsider but He's Really Just Another Member of the Guild', New Statesman, 24 June.

Corbett, R. (1998) The European Parliament's Role in Closer European Integration. London: Macmillan.

Corbett, R., Jacobs, F. and Shackleton, M. (2011) The European Parliament (8 ${ }^{\text {th }}$ edn.). London: John Harper.

Crewe, E. (2015) The House of Commons: An Anthropology of MPs' Work. London: Bloomsbury.

Dalton R. (2004) Democratic Challenges Democratic Choices: The Erosion of Political Support in Advanced Industrial Democracies. Oxford: Oxford University Press.

Decreus, T. (2013) 'Beyond Representation? A Critique of the Concept of the Referent', Representation, 49(1), 33-43.

Deloitte (2014) Palace of Westminster Restoration and Renewal Programme Independent Options Appraisal: Final Report, available at: http://www.parliament.uk/documents/lordsinformation-office/2015/Independent-Options-Appraisal-final-report-A4.pdf

Disch, L. (2015) 'The "Constructivist Turn" In Democratic Representation: A Normative DeadEnd?', Constellations, 22(4), 487-99.

Easton, D. (1965) A Systems Analysis of Political Life. New York: Wiley.

EMBT (1998) Scottish Parliament Building. Barcelona: Enric Miralles Benedetta Tagliabue Architects available http://www.scottish.parliament.uk/VisitorInformation/4.Enric Miralles Moya.pdf.

European Parliament (2009) Altiero Sinelli - European Federalist, PE410.673. Brussels: DG Internal Policies, Citizens' Rights and Constitutional Affairs.

Goodsell, G. (1988). 'The Architecture of Parliaments: Legislative Houses and Political Culture', British Journal of Political Science, 18(3), 287-302.

Hannan, D. (2015) 'The objective correlative of the EU' available at: http://www.hannan.co.uk/new-criterion-the-objective-correlative-of-the-e-u/

Hansard Society (2006) Reaching the Public: An Examination of Options for Parliamentary Outreach. London: Hansard Society.

Hansard Society (2010) Lessons From Abroad: How Parliaments Around The World Engage With Their Public. London: Hansard Society

Hayward, C. (2009) 'Making Interest: On Representation and Democratic Legitimacy', in I. Shapiro, S. Stokes, E. Wood and A. Kirshner (eds.), Political Representation. Cambridge: Cambridge University Press. 
HC 697 (2012) Select Committee Effectiveness, Resources and Powers, House of Commons Liaison Committee, Volume 2, Second Report Session 2012-13. London: Stationery Office.

IPU (2012) Global Parliamentary Report: The Changing Nature of Parliamentary Representation. Geneva: Inter-Parliamentary Union.

Johns, R. and Mitchell, J. (2016) 'Takeover: Explaining the Extraordinary Rise of the SNP'. London: Biteback.

Judge, D. (2005) Political Institutions in the United Kingdom. Oxford: Oxford University Press.

Judge, D. (2014) Democratic Incongruities: Representative Democracy in Britain. Houndmills, Basingstoke: Palgrave Macmillan.

Judge, D. and Earnshaw, D. (2008) The European Parliament, 2nd edn. Houndmills, Basingstoke: Palgrave Macmillan.

Keating, M. (2009) The Independence of Scotland: Self-Government and the Shifting Politics of Union. Oxford: Oxford University Press.

Kelso, A. (2007) 'Parliament and Political Disengagement: Neither Waving nor Drowning' Political Quarterly, 78(3), 364-73.

Laursen, B. and Valenti, C. (2014) 'Mediatization and Government Communication: Press Work in the European Parliament', The International Journal of Press/Politics, 20(1), 2644.

Leston-Bandeira, C. (ed.) (2013) Parliaments and Citizens. London: Routledge.

Leston-Bandeira, C. (2014) 'The Pursuit of Legitimacy as a Key Driver for Public Engagement: The European Parliament Case'. Parliamentary Affairs 67 (2): 415-436.

Leston-Bandeira, C. (2016) 'Why Symbolic Representation Frames Parliamentary Public Engagement'. The British Journal of Politics \& International Relations 18 (2): 498-516.

Lombardo, E. and Meier, P. (2014) The Symbolic Re presentation of Gender: A Discursive Approach. London: Ashgate.

Lord, C. and Pollak, J. (2013) 'The Pitfalls of Representation as Claim Making in the European Union' Journal of European Integration, 35(5), 517-30.

Lowndes, V. and Roberts, M. (2013) Why Institutions Matter: The New Institutionalism in Political Science. Houndmills: Palgrave Macmillan.

March, J. G. and Olsen, J. P. (1989) Rediscovering Institutions: The Organizational Basis of Politics. New York: Free Press.

Mair, P. (2009) 'Representative Versus Responsible Government', MplfG Working Paper 09/8. Cologne: Max Plank Institute for the Study of Societies.

McCrone, D. (2005) 'A Parliament for the People: Holyrood in an Understated Nation', Scottish Affairs, 50(Winter), 1-25.

McNamara, K. (2015a) 'Building Culture: The Architecture and Geography of Governance in the European Union', in S. Börner and M. Eigmüller (eds.), European Integration, Processes of Change and the National Experience. Houndmills: Palgrave Macmillan.

McNamara, K. (2015b) The Politics of Everyday Europe: Constructing Authority in the European Union. Oxford: Oxford University Press.

Mitchell, J. (2004) 'Scotland: Expectations, Policy Types and Devolution', in A. Trench (ed.) Has Devolution Made a Difference?: The State of the Nations 2004. Exeter: Imprint Academic Press.

Mitchell, J. (2010) 'The Narcissism of Small Differences: Scotland and Westminster', Parliamentary Affairs, 63(1), 98-116.

Mitchell, J. (2014) The Scottish Question. Oxford: Oxford University Press.

Näsström, S. (2011) 'Where is the Representative Turn Going?', European Journal of Political Theory, 10(4), 501-10.

Norris, P. (2011) Democratic Deficit: Critical Citizens Revisited. Cambridge: Cambridge University Press

Parkinson, J. R. (2012) Democracy and Public Space: The Physical Sites of Democratic Performance. Oxford: Oxford University Press.

Pitkin, H. (1967) The Concept of Representation. Berkeley: University of California Press.

Priestley, J. (2008) Six Battles that Shaped Europe's Parliament. London, John Harper.

Rai, S. (2010) 'Analysing Ceremony and Ritual in Parliament', Journal of Legislative Studies, 16(3), 284-297. 
Rai, S. and Johnson, R. (2014) Democracy in Practice: Ceremony and Ritual in Parliament. Houndmills: Palgrave Macmillan.

Rittberger, B. (2005) Building Europe's Parliament. Democratic Representation Beyond the Nation-State. Oxford: Oxford University Press.

Rorabaugh, W. (1973) 'Politics and Architectural Competition for the House of Parliament 1834-1837', Victorian Studies, 17(2),155-75.

Roth, L. and Roth Clark, A. (2014) Understanding Architecture: Its Elements, History and Meaning ( ${ }^{\text {rd }}$ edn.). Boulder CO: Westview Press.

Rothstein, B. (1996) 'Political Institutions: An Overview”, in R.E. Goodin and H-D. Klingemann (eds.), A New Handbook of Political Science. Oxford: Oxford University Press.

Saward, M. (2006) 'The Representative Claim', Contemporary Political Theory, 5(3), 297-318.

Saward, M. (2010) The Representative Claim. Oxford: Oxford University Press.

Shenton, C. (2016) Mr Barry's War. Oxford: Oxford University Press

Smith, G. (2009) Democratic Innovations - Designing Institutions for Citizen Participation. Cambridge: Cambridge University Press.

Spring, M. (2010), 'Scottish Parliament: Miralles' Magnificent Mess Revisited', Building Magazine, available at: http://www.building.co.uk/scottish-parliamentmiralles\%E2\%80\%99-magnificent-mess-revisited/3156995.article.

Therborn, G. (2014) 'Modern Monumentality: European Experiences', in J. Osborne (ed.) Approaching Monumentality in Archaeology. New York: State University of New York Press.

UK Parliament (2015a) Living Heritage: Westminster Hall Early History, available at: http://www.parliament.uk/about/livingheritage/building/palace/westminsterhall/architecture/early-history/.

UK Parliament (2015b) Living Heritage: Architecture of the Palace, available at: http://www.parliament.uk/about/livingheritage/building/palace/architecture/palacestructure/new-gothic-vision/

UK Parliament (2016) Departments of the House of Commons, available at: http://www.parliament.uk/mps-lords-and-offices/offices/commons/departments/\#jumplink-4.

Urbinati, N. and Warren, M. (2008) 'The Concept of Representation in Democratic Theory', Annual Review of Political Science, 11, 387-412.

Walker, A. (2012) 'A People's Parliament?', Parliamentary Affairs, 65(1), 270-80.

\section{Appendix 1}

List of Key Parliamentary Interviewees (out of the total of 39)

Interview 1 (2010) Official, European Parliament. Interview 2 (2010) Official, European Parliament. Interview 5 (2010) Official, European Parliament. Interview 6 (2010) MEP, European Parliament.

Interview 7 (2011) Official, European Parliament. Interview 9 (2011) Official, European Parliament. Interview 11 (2010) Official, UK Parliament. Interview 13 (2010) Official, UK Parliament. Interview 16 (2010) MP, UK Parliament. Interview 18 (2010) Official, UK Parliament. Interview 21 (2011) MP, UK Parliament. Interview 26 (2010) Official, Scottish Parliament. Interview 27 (2010) MSP, Scottish Parliament. Interview 29 (2010) MSP, Scottish Parliament. Interview 32 (2011) Official, Scottish Parliament. Interview 33 (2011) Official, Scottish Parliament. Interview 43 (2011) Official, UK Parliament. Interview 56 (2013) Official, UK Parliament. 


\section{Notes}

${ }^{1}$ This 'first dimensional' model assumes an unmediated simple principal-agent relationship between elected representatives and individual citizens, which depends, paradoxically, upon this relationship being mediated through 'constituencies' designed to organise individual voters into collectivities; incorporates notions of political equality into electoral representation through the universal franchise, and holds that legitimacy flows from a set of procedural standards of authorisation and accountability associated with free and fair elections to representative institutions (for summaries of this model see Urbinati and Warren 2008:389; Hayward 2009:111; Alonso et al. 2011:2-6; Author 2014:1-4; Disch 2015:489).

${ }^{2}$ The significance of Saward's ideas for parliamentary scholars has been recognised, for example, by Author (2014); Author (2016), Crewe (2015); shortcomings of notions of representative claims, of relevance to students of legislatures, have been noted by Author $(2013 ; 2014)$, Childs and Lovenduski (2013); Lord and Pollak (2013).

${ }^{3}$ Our focus here is exclusively on parliamentary architecture, for wider discussions of the importance of symbolic representation in legislatures see, for example, Author (2016); Crewe (2015); Rai 2010; Rai and Johnson (2014). 